\title{
Etruscan Hedonism, Women, and Cruelty - Interpretation of Ancient Writings and Archaeological Sources
}

Kristína Rašlová

(Masaryk University, Brno)

\begin{abstract}
Etruscan control in Italy was not constrained distinctly by the well-known region of Etruscan culture (Tuscany and northern Lazio). The Etruscan power also extended toward the southwestern areas (Campania) as well as to the northern parts of Italy (Po valley). The impact of Etruscan culture spread over the entire land. The essential wellsprings of the paper are represented by the ancient sources in Latin and Greek from different periods treating Etruscan culture and society. The ancient authors portrayed the high class of society intentionally. They planned to define Etruscans as pleasure-seekers that participated in the spectacular banquets. The truth of the matter, from an archaeological perspective, is that it was not completely real. Archaeobotanical and anthropological investigation demonstrates that the way of life of the vast majority of the Etruscan population was standardly modest. Comparison of ancient written sources with archaeological data proves that the ancient writers were one-sided, sometimes without a critical approach to the sources, which could cause the misconception of certain components of Etruscan culture. There could be several reasons why it was so. The main focus of this paper is the examination of these reasons.
\end{abstract}

\section{Keywords}

Etruscans; morality; ethics; written sources; Latin; Greek; archaeological sources 


\section{Introduction}

The paper aims to the explanation of the literary stereotype of Etruscan hedonism and moral corruption. The leading role of Etruscan power in central Italy was not limited only by the traditional main area of Etruscan culture (Tuscany and northern Lazio). The Etruscan civilization expanded to the south-western regions (Campania) and the northern parts of Italy (Po valley). The influence of Etruscan culture was spread across the peninsula (from Campania to Bologna) and beyond (north and central Europe, Iberian Peninsula, North Africa, etc.), mainly thanks to the growth in commercial contacts. Interdisciplinary approach (for example between archaeology, philology, and archaeobotany) involves many positive comparative alternatives in the investigation of the Etruscan issue. Although archaeological sources are an important and, above all, more reliable source of information (thanks to this we can understand how the Etruscan society worked) written sources and fragments of ancient authors complete the contemporary context and therefore should not be underestimated. Since Etruscan's written sources have not been preserved, it is necessary to draw on secondary sources, which are not entirely objective. The sources of the paper are represented by ancient texts in Latin and Greek (including poetry, oratory, historical and geographical works, and others) from diverse periods treating Etruscan culture and society.

\section{The land that bears every crop...}

In antiquity, the writers of historical works had similar background to the orators, poets or even philosophers. ${ }^{1}$ The most significant writings about Etruscans are those dealing with their morals and ethics. The paper takes into account authors from those contemporary to the Etruscans up to $4^{\text {th }}$ century AD to demonstrate the probable influences and impacts on the writers' thinking. The greatest emphasis has been put on the comparison of Greek and Latin texts of diverse periods, finding the questionable parts of the opinions of authors about Etruscan morality, followed by the correlation with archaeological sources.

A general, but understandable and comprehensive characteristic of Etruscan society,

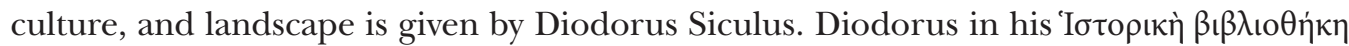
writes about ancient times, in which the Etruscans had power over a vast territory and founded many remarkable cities. They used their maritime skills and maintained their domination at sea for a long time. They should be the authors of signs of power. Already Etruscan lucumones (Lauxmes) ${ }^{2}$ used liquors, ivory chairs or toga with a purple belt, which later the Romans took over and projected into their political institutions. ${ }^{3}$

1 Marincola (2011: p. 8).

2 Lauchme or Lauchume is indicated as a personal name (particularly as a praenomen, but also as a nomen or cognomen) in Etruscan texts of the $5^{\text {th }}$ to $2^{\text {nd }}$ centuries BC. Scholars have assumed that this could be a late tradition of the personal name transformation to an institutional term (Tagliamonte 2017: p. 125). 
He continues:

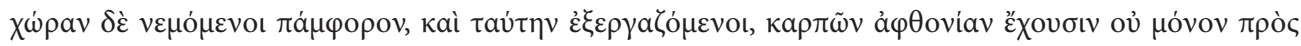

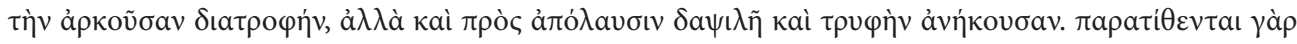

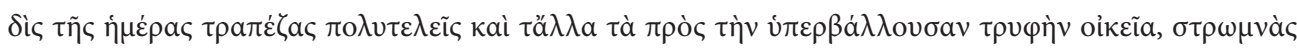

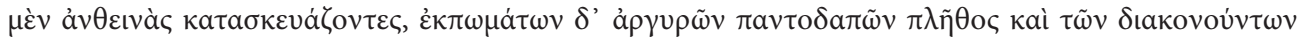

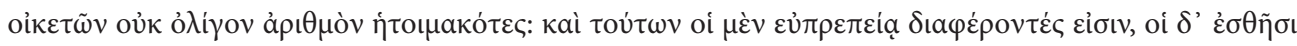

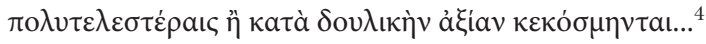

"The land the Tyrrhenians inhabit bears every crop, and from the intensive cultivation of it they enjoy no lack of fruits, not only sufficient for their sustenance but contributing to abundant enjoyment and luxury. For example, twice each day they spread costly tables and upon them everything that is appropriate to excessive luxury, providing gay-coloured couches and having ready at hand a multitude of silver drinking-cups of every description and servants-inwaiting in no small number; and these attendants are some of them of exceeding comeliness and others are arrayed in clothing more costly than befits the station of a slave." ${ }^{5}$

Diodorus also mentions that in his time ( $1^{\text {st }}$ century $\left.B C\right)$ it was used to say how the Etruscans had resigned themselves to a kind of "spirit of civilization" carried by their ancestors. They only went through life with drinking and insignificant pastimes. That is why it is very easy to understand how they lost their glory in the struggle that their fathers had acquired.

He further writes that what contributed most to the Etruscan luxury was the fertility of the territory. Other authors also discuss Etruscan places for their marvellous olives, figs, and vineyards. ${ }^{6}$ It was very fertile land, and they based their business and livelihood on it. Subsequently, Diodorus provides a brief description of the country and thus closing the story of the Etruscans. ${ }^{7}$

Therefore, what we could state is that Diodorus Siculus gives a fairly neutral description of Etruscan culture. In essence, he does not blame them, but rather emphasizes the Etruscan faded glory. During this period, the Etruscans posed no moral or military threat to the increasingly expanding Roman control.

On the contrary, Plautus $\left(3^{\text {rd }} / 2^{\text {nd }}\right.$ centuries BC) in Cistellaria (The Casket Comedy) or Curculio (The Weevil) is no restrained and points out that in Etruria it is typical for residents to sell their bodies. ${ }^{8}$ Later Catullus $\left(1^{\text {st }}\right.$ century BC), in his $39^{\text {th }}$ poem, uses

3 Diod. Sic. V 40, 1.

4 Diod. Sic. V 40, 3.

5 Oldfather (1939: p. 209).

6 Dion. Hal. Ant. I 37, 1-4; Liv. V 33; Plut. Cam. XV 1-6.

7 Diod. Sic. V 40, 5.

8 Plaut. Cis. II 3, 20; Curc. IV 1, 21. 
the phrase obesus Etruscus. ${ }^{9}$ A similar term pinguis Tyrrhenus (fattened Tyrrhen) is also used in Vergilius $\left(1^{\text {st }}\right.$ century BC). ${ }^{10}$

In Dionysius Halicarnanensis ( $1^{\text {st }}$ century $\mathrm{BC}$ ), there is a reference to the Tyrrhenian nature several times, comparing them to the homeless, vagabonds and barbar-

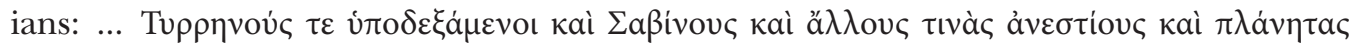

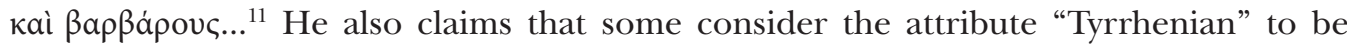
something rogue and fraud. ${ }^{12}$ Horatius ( $1^{\text {st }}$ century BC) writes in his satires that vicus tuscus in Rome was full of the wicked rabble. ${ }^{13}$ And Livius is outraged by the decadence of Etruscan society and writes that huius mali labes ex Etruria Romam veluti contagione morbi penetrauit. ${ }^{14}$ With immorality (evil) means orgies during the Bacchanalia in Rome. Aelianus $\left(2^{\text {nd }} / 3^{\text {rd }}\right.$ centuries $\left.\mathrm{AD}\right)$ also characterizes Etruscans as the cause of evil things and describes them as unrestrained, violent and lazy. ${ }^{15}$

According to J. M. Turfa, even the term etruscus, a Latin term for the Etruscans, had a pejorative, or even disrespectful meaning because it is not a term by which the Etruscans (Rasenna $)^{16}$ used to refer to themselves. ${ }^{17}$

The Etruscan archaeological findings from Latium show very intense mutual contacts between Etruria and Rome. The development of a common style, including similar decorative elements, has been taken over probably from Veii at the end of the $7^{\text {th }}$ century BC. Under the rule of Etruscan kings, occurs the unprecedented development, and urbanization, of Rome. However, from the $4^{\text {th }}$ century BC, connections with Rome began to change. Rome continued in expansionist policy and thus conquered the whole of Latium, and subsequently the Etruscan cities.

In the $3^{\text {rd }}$ century $\mathrm{BC}$, the character of Roman expansion stimulated the formation of an alliance of Etruscans, Umbrians, Samnites, and Gauls to resist them. ${ }^{18}$ Rome triumphed at Sentinum (295 BC) and Aquilonia (293 BC). The alliance struggled with the Roman territorial integrity, consolidated leadership, and military organization. The Samnites and Umbrians were defeated by 290 BC. Etruscans and Gallic Senones destroyed at Vadimon (283 BC)..$^{19}$

These events represent the end of the Etruscan political authority as recently summarised by L. Ceccarelli. ${ }^{20}$

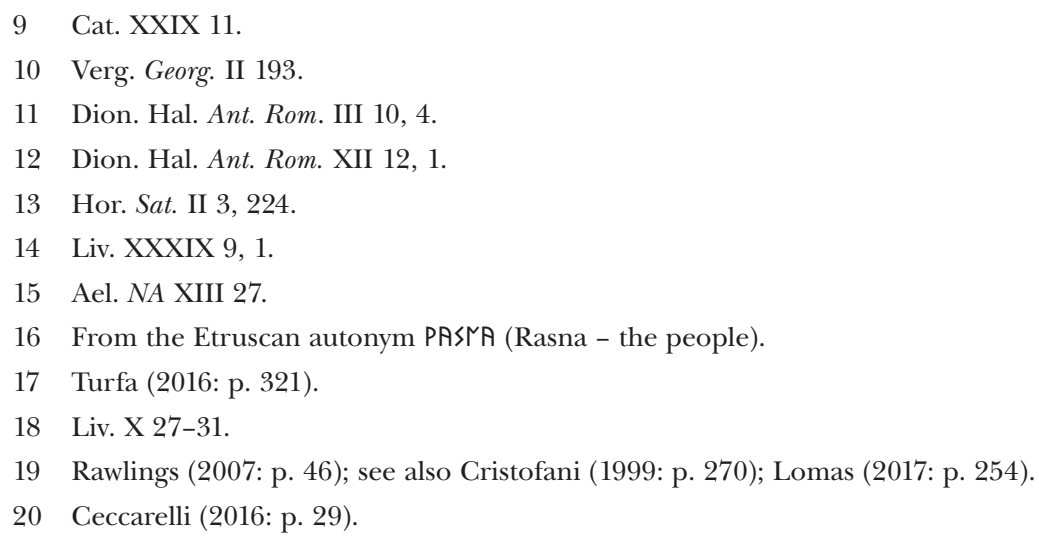




\section{Obesus Etruscus}

Over the centuries, the Etruscans were perceived to be excluded from ancient societies (especially from Roman society) for their immoral acts. Their reputation has suffered from the material success of their own culture. Already Catullus, ${ }^{21}$ later Vergilius,${ }^{22}$ labelled them for future generations of writers as overweight enjoyers. J. M. Turfa attempted to objectively summarize and interpret the probable reality of Etruscan hedonism based on multidisciplinary research, including mainly archaeological findings. Thanks to the relevant archaeological work and scientific analysis of vessels, it is possible to begin to discover more about Etruscan food consumption. This field encourages us to expand understanding of the Etruscan diet and improve knowledge of the social and cultural implications of food. ${ }^{23}$

If the comparison of the Etruscans to overweight people (in the case of Catullus and Vergilius) was based on paintings and tombstones in Etruscan graves (where the Etruscans are, indeed, portrayed as robust individuals with massive heads and wide hands), it should be remembered that both Vergilius and Catullus were authors of the Augustan age (31 BC-14 AD) and monuments referring to corpulent Etruscans were placing in the tombs from $4^{\text {th }}$ century BC to the second half of the $2^{\text {nd }}$ century BC.

This indicates that both authors probably had to depend on an earlier tradition. ${ }^{24}$ The question remains, whether they referred to real people or to artistic images, which could have been misinterpreted.

When referring to an older tradition, Roman poets chose, at the time of their crisis (the end of the Republic), a depiction of the once significant Etruscan warriors in a tamed and settled position.

From an archaeological and anthropological point of view, the research on skeletal remains of the Mediterranean population showed only a negligible amount of obesity-related consequences and, moreover, those documented cases were not Etruscans (mainly skeletal remains of the Romans).

The composition of the Etruscan diet provides information in addition to artistic illustrations and analysis of plant and animal remains. However, although data from shrines and tombs are useful, they cannot be considered representative, offerings to those shrines depend on a specific system of gifts of different cults, which were often distant by traditional eating habits, and the tombs have had a dish of specific quality and quantity. Therefore, the most reliable sources are dwellings based on which it is possible to build a balanced reconstruction of Etruscan meals. ${ }^{25}$

Excellent support is the chemical analysis (trace element analysis, stable isotope ratio analysis) of the discovered bones and teeth, which confirms that the Etruscan diet was

\footnotetext{
21 Cat. XXXIX 11.

22 Verg. Georg. II 193.

23 Pieraccini (2013: p. 819).

24 Turfa (2016: p. 323).

25 Colivicchi (2017: p. 217).
} 
mainly composed of vegetable components. Similarly, the findings of fauna and flora help to complete the authentic form of Etruscan diet. ${ }^{26}$ According to archaeobotanical data, the primary segment of the common Etruscan diet consisted mainly of cereals and legumes. ${ }^{27}$ Other foods included olives and figs. Neither meat nor wine was likely to form part of regular Etruscan meals. ${ }^{28}$ Meat consumption was irregular and probably only occurred during major events or at religious festivals or public and private ceremonies. ${ }^{29}$

\section{Women and banquets}

Ancient authors are regularly offended by the freedom of Etruscan women. Despite the fact, that the primary duties of Etruscan women lay in the position of childbearing and the household circle. Exceptional responsibilities outside the home, for example, cultic obligations, might be accepted. From the political life and state organization, were Etruscan women excluded. However, the Etruscan woman performed through a public presence. They took part in high society feasts at home and outdoor, they were present in the audience for games, and as mothers, they had respect inside their families like that of the Roman matrona. ${ }^{30}$

The high-ranking women in Etruria did not only accompany the husbands during the banquets, but this situation was also glorified in the iconography on the murals from the tombs (especially during the $6^{\text {th }}-4^{\text {th }}$ centuries BC).$^{31}$ It symbolizes a pleasant entertainment. The Greek iconographic forms, were modified according to the views of the tombs' owners, to corresponding with the Etruscan social structure. It also includes the presence of the wives, which was not denied or unique. ${ }^{32}$ Ancient sources in the case of women's participation in banquets speak of historical fact, but this is a very different custom than from those applied to the Greek symposium or the Roman banquet. ${ }^{33}$

The antiquarian Athenaeus Naucratita ${ }^{34}$ describes Etruscan feasts by Theopompus, the author of the $4^{\text {th }}$ century BC. He supposed that among the Tyrrhenian customs was that of sharing their women between all men, and that is why they put so much emphasis on body care. Women exercised together with men, and it was not humiliating for them

26 Ibid., p. 207.

27 Becker (2006: p. 19).

28 Ibid., p. 22.

29 Colivicchi (2017: p. 218).

30 Amann (2017: p. 185); see also Della Fina (2005: pp. 19-24); Cristofani (1999: pp. 108-109); for the closer discussion see Rallo (1989).

31 Similar scenes also occur on decorative terracotta panels - including the archaic building complex of Poggio Civitate (Murlo).

32 Amann (2017: p. 988).

33 Becker (2016: p. 297).

34 Ath. XII 517d-518b. 
to show themselves naked. At the feast, they did not eat privately with their husbands, but with anyone present. ${ }^{35}$

Theopompus condemns Etruscan women, perhaps for fear of their freedom. Greek women were far below this status (except for Hetaerae and priestesses). Aristoteles also writes that the Tyrrhenians dine with their wives even under one cloak. Athenaeus referring to Aristoteles ${ }^{36}$ states that they are extremely exuberant and that their servants at the banquet serve naked. ${ }^{37}$

Posidonius Apamensis ( $2^{\text {nd }} / 1^{\text {st }}$ centuries $\left.\mathrm{BC}\right)$, the successor of Polybius, preserved only in fragments ${ }^{38}$ writes that the Tyrrhenians used to prepare rich feasts twice a day, had flower carpets on the ground, silver cups of every kind on the tables and served by a crowd of beautiful slaves dressed in plush clothing. ${ }^{39}$

These banquets have symbolized the status of elite since the Orientalising period. Funeral banquets, however, are also depicted on the urns from the Villanovan period, but still in the form of schematic seated figures. Individuals with specific status of principes, which arose as a result of formation processes of aristocratic clans in Etruria, show a life-

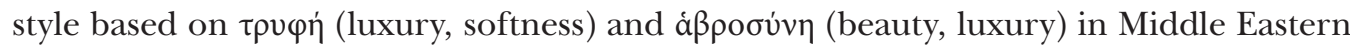
forms.

The banquet is one of the main expressions of the elite lifestyle. In later times, it was such a crucial custom that in the southern part of Etruria it replaced the original role of warrior importance in burial practices. This type of banquet had a very hierarchical undertone, especially in the Orientalising period, but the gradual integration, and later relative equality between the participants was supposed to create an even stronger form of the elitism of the ruling segment. ${ }^{40}$

In the $6^{\text {th }}$ century BC, the Etruscan image of the banquet seems more like a Greek symposium. This is indicated by the iconography on the architectural terracotta of Murlo (580-570 BC), which depicts a man and a woman on deck chairs with a cauldron at their feet, and servants with wine. This scene evokes contemporary depictions in Greek vase painting. ${ }^{41}$

The presence of an Etruscan (unmarried) woman at a banquet could have caused a wave of disgust and shock to Roman and Greek authors. However, the inscriptions on the containers confirm the woman's role as a guardian and wine distributor. This custom comes from the strongly aristocratic basis of Etruscan society, which gave the elite woman not only status but also a measure of freedom. ${ }^{42}$ Although the burial paintings

35 Theopomp. fr. 222.

36 Ath. I 23d.

37 Aristot. fr. 565.

38 Ath. IV 153c-d.

39 Posidon. fr. 1.

40 Colivicchi (2017: pp. 208-210); see also Rossi (2013: pp. 43-45); Cristofani (1999: pp. 35-36).

41 Colivicchi (2017: p. 212).

42 Ibid., p. 214. 
of the $5^{\text {th }}$ century BC are even more similar to Greek depictions (mainly attic models), women are still often depicted as attending a banquet even in this period. ${ }^{43}$

\section{Etruscan piracy and cruelty}

Another shameful act Etruscans were regularly accused of in ancient sources was piracy. ${ }^{44}$ Etruscan pirates were a well-known element in antiquity that existed outside the social community and operated in a wide area of the ancient Mediterranean. ${ }^{45}$ Even the Homeric hymns ${ }^{46}$ mention Etruscans as pirates who appear in the anthem of Dionysios. ${ }^{47}$ Later the story takes over Philostratus $\left(2^{\text {nd }} / 3^{\text {rd }}\right.$ centuries AD) ${ }^{48}$ Etruscan maritime skills are also discussed in C. Plinius Secundus ( $1^{\text {st }}$ century AD). ${ }^{49}$ A lot of allusions are possible to find in other ancient sources. In 384 BC the Syracusans, to fund a war against the Carthaginians, plunder the Pyrgi sanctuary, gaining capital on the excuse that they are freeing the Tyrrhenian basin from Etruscan pirates. ${ }^{50}$ Later, in 325-324 BC, the Athenians decide to send settlers to the Adriatic to defend their trade activities from the Etruscans. ${ }^{51}$ In 299 BC the Delians spend thousands of drachmas in preparing their protection against Etruscan pirates. ${ }^{52}$ Lastly, in the $3^{\text {rd }}$ century BC the Etruscans, in their pirates' position, are paid by the Argives to steal the statue of Hera from the temple of Samos. ${ }^{53}$

The phenomenon of Etruscan piracy during the second half of the $4^{\text {th }}$ century had reached a notable extent and was not defined only by the Adriatic region. For example, the Etruscans of southern Etruria, or the group from Campania, were attacking Magna Graecia and against whom the first Alexander, in 334 BC, and then, near the end of the $4^{\text {th }}$ century BC, Demetrius Poliorcetes, inquired Rome to defeat them. ${ }^{54}$ Archaeologically, there is no indication to identify people practicing piracy in the finds of the Etrus-

43 Ibid., p. 216.

44 Diod. Sic. V 9, 3; XI 88, 1; Str. V 3, 5; VI 2, 2; Ath. XV 12; etc.

45 Isayev (2016: p. 24); Cristofani (1999: pp. 221-222); various acts were attributed to Etruscan pirates, such as the stealing of statue of Hera from the island of Samos, the rape of Brauron women or the looting of Athens (Plut. Mulier. 8; Plut. Quaest. Graec. 21; Philochor. fr. 5).

46 The poems are, in fact, of diverse date and origin, although the majority are presumably appearing in the archaic period $\left(7^{\text {th }}\right.$ to $6^{\text {th }}$ centuries $\left.\mathrm{BC}\right)$.

47 H. Bacch. 1-10.

48 Philostr. Imag. I 19, 3.

49 Plin. HN VII 56, 209.

50 Diod. Sic. XV 14, 3; Aristot. Econ. II 1349b; Ael. VH I 20; Polyaenus, Strat. V 2, 21.

51 IG II 1629, 220.

$52 I G$ XI 2, 148.

53 FHG XV 671 F; see Camporeale (2016: p. 81).

54 Memnon, FGrHist 434 F 18; Str. V 3, 5; see also Bruni (2013: p. 765). 
can necropoleis. Neither in Spina, which after the Celtization of the Po valley in the $4^{\text {th }}$ century BC, had to be the nucleus of Etruscan piracy in the Adriatic region. ${ }^{55}$

Ancient sources also refer to the cruelty of the Etruscans ${ }^{56}$ and mention several cases, including human sacrifices. These cover the ritual sacrifices after the Battle of Lipari in the early $5^{\text {th }}$ century BC when the Etruscans killed the enemy as a sacrifice to God Apollo. Livius states that the Romans were sacrificed in $307 \mathrm{BC}$ at the Tarquinia Forum. ${ }^{57}$ Likewise, Herodotus $\left(5^{\text {th }}\right.$ century BC) in his work mentions the sacrifice after the battle of Alalia around 540 BC when the Etruscans along with the Carthaginians

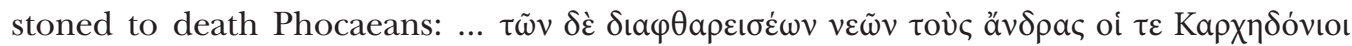

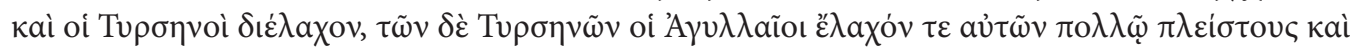

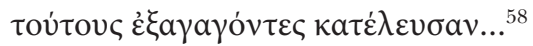

From the archaeological point of view, the crucial illustration of Etruscan cruelty could represent funerary paintings. For example, archaeologists have earlier discovered depictions of a Phersu (funerary game) inside four tombs in Tarquinia. ${ }^{59}$ During the Hellenistic period, the illustration of myths entered funerary art. The frescoes in the Tomb of the Bulls (Tarquinia) and the François tomb (Vulci) remain exceptions in the meaning of the funerary context. The paintings showed certain affection for the depiction of attack, fight, and murder. These are the scenes that caused the Etruscans the accusation of having an unusual inclination for cruelty. The Greek mythological scenes in these tombs were regularly not reproduced correctly so that the interest seemed to apply less to the myth than to their cruel nature.$^{60}$ In much past scholarship, these representations are frequently described not only as especially Etruscan (as opposed to Greek) in taste but also as significatory of an unusual desire for savagery and its depiction. ${ }^{61}$ G. Bonfante, when explaining the issue of cannibalism in Dante, wrote that: "The Etruscans, as is well known, favoured in their art bloody descriptions of horrors: a glance at the François Tomb is sufficient to prove it. Among all the Greek myths they preferred these." ${ }^{2}$

However, within the sanctuary, there was no better way to connect the power and authority of the gods than by showing, strongly, and dramatically, the terrible punishments to mortals. In the funerary context, the motif of violent death dominated to satisfy the religious and ritual duties of the deceased rather than to fulfil an inclination for blood and slaughter. Moreover, as A. Carpino noted, these scenes are in the minority, and their appearance must be the result of a thoughtful selection. Therefore, the violent

55 Ibid., p. 766.

56 Str. V 1, 7.

57 Liv. VII 19, 3.

58 Hdt. I 167.

59 Phersu was a barbarously cruel form of the game in which a person pulled on a chain, causing a nail on a dog's collar to dig into the animal's neck to provoking it to attack a man.

60 Krauskopf (2016: p. 401).

61 Carpino (2016: p. 410).

62 Bonfante (1998: p. 5). 
representations in Etruscan art cannot be considered as indicators of a peculiar appetite for bloody or horrific imagery. ${ }^{63}$

Nevertheless, in ancient sources, Etruscan customs and morality were considered rather unfavourably. ${ }^{64}$ The authors writing about the Etruscans often criticized them for cruelty, inappropriate sexual behaviour, or inappropriate behaviour of women in society.

The condemnation of Etruscan customs by Greek and Roman authors was probably due to the difference from typical ancient societies. Conflicts between ancient cultures arose from varying customs and beliefs. Greek and Roman authors called Etruscans barbarians and foreigners. Their non-Indo-European language distinguished them and at the same time slightly isolated them from the Romans. The sources say they were supposed to live in an opulent and decadent way of life..$^{65}$

The fact that they got out of their common habits made the ancient authors perceive this distinctness as amoral. Due to their differences, the sources often say that the Etruscans do not represent the autochthonous population of Italy, but that they come from the territory of Asia Minor, or that of the Raetia, across the Alps. Naturally, it was easier to assume that they were foreigners, as they differed significantly from neighbouring tribes. ${ }^{66}$ However, according to other ancient sources and also current authors ${ }^{67}$ it seems to be the most probable autochthonic theory. Although it is possible to observe very strong eastern (orientalising) impacts in Etruscan culture, this could indicate that at least some of the settlers shaping the Etruscan culture may have come from Asia Minor.

\section{Conclusion}

The literary stereotype of overweight Etruscan (obesus Etruscus), decadent banquets and cruelty behaviour recurring by Latin and Greek writers was based (apparently purposely) on feasting elite and misinterpretation of their beliefs. In the context of the Roman resistance to private luxury, the Etruscans could be used as a repulsive example in which the former mighty "nation" was destroyed by hedonism and moral corruption. ${ }^{68} \mathrm{H}$. Becker considers that the topoi, which repeatedly discuss Greek and Latin texts on the Etruscans, are not primarily directed to them. Roman culture and the elite of society were afraid of behaviour and values that it considered undesirable and unacceptable. Negative promotion of Etruscan topoi, in terms of excessive decadence and wealth, acted as a deliberate distortion and strengthening of the Greek and Roman traditions. ${ }^{69}$

63 Carpino (2016: p. 426).

64 Some ancient authors have positive allusions to Etruscan knowledge and religious practices (see for example Liv. V 1,6).

65 Bonfante Warren (1973: p. 242).

66 Beekes (2003: p. 33).

67 See for example Pallottino (1942: p. 51); Weeber (1979: p. 31); Barker \& Rasmussen (2005: p. 84); Stoddart (2016: p. 13), etc.

68 Colivicchi (2017: p. 218).

69 Carpino \& Bell (2016: p. xxvi). 
To summarise, there could be several reasons to explain this. On the one hand, we could assume that the individual authors did so because they did not know this way of living and did not understand the elements of the Eastern influence coming into the Etruscan culture during the crucial and intensive Orientalising period. On the other hand, they feared (especially the Romans) that the established system of their own society could be disrupted. The authors tended to protect their culture by pointing to the evil Etruscan morals that caused their fall.

From an archaeological point of view, however, it is obvious that the opinion of the ancient authors was not correct. Although a higher layer of principes and a ruling part of society were wealth and could organize banquets described in the works of the authors (and the paintings from the tombs show that they probably did), most of the population did not have the sources. The archaeobotanical analysis shows that the Etruscans ate simple Mediterranean meals that did not differ significantly from other diets.

Authors described the upper class of society on purpose. They intended to depict Etruscans as opulent hedonists, who took part in the spectacular banquets. Archaeologically, this was not accurate (at least in general). Archaeobotanical and anthropological analysis proves that the lifestyle of the largest part of the Etruscan population was standardly average. Interpretation of ancient writings and correlation with archaeological sources verifies that the ancient authors were biased. Sometimes without a critical approach to sources, this could cause a misunderstanding of some elements of Etruscan society.

\section{Bibliography}

\section{Primary Sources}

Armstrong, G. C. (Transl.). (1935). Aristotle in 23 Volumes (Vol. 18). Cambridge: Harvard University Press; London: William Heinemann Ltd.

Babbitt, F. C. (Transl.). (1914). Plutarch's Lives. London: William Heinemann Ltd.

Babbitt, F. C. (Transl.). (1931). Plutarch: Moralia. London: William Heinemann Ltd.

Bekker, I., Dindorf, L., \& Vogel, F. (Eds.). (1888-1890). Diodorus Siculus: Bibliotheca Historica (Vol. 1-2). Leipzig: B. G. Teubner.

Burton, R. F., \& Smithers, L. C. (Transl.). (1894). Catullus: Carmina. London.

Didot, A. F., \& Müller, K. O. (Eds.). (1848). Fragmenta historicorum Gracorum ...: Apollodori Bibliotheca cum fragmentis (Vol. 3). Parisiis: Didot.

Dürrbach, F. (Ed.). (1912). Inscriptiones Graecae XI, 2: Inscriptiones Deli (IG XI,2; Nos. 105-289). Berlin: Reimer.

Evelyn-White, H. G. (Transl.). (1914). The Homeric Hymns and Homerica. London: William Heinemann Ltd.

Godley, D. (Transl.). (1920). Herodotus. Cambridge: Harvard University Press.

Greenough, J. B. (Ed.). (1900). Bucolics, Aeneid, and Georgics of Vergil. Boston: Ginn \& Co. 
Hercher, R. (Ed.). (1864). Claudius Aelianus: De natura animalium libri xvii, varia historia, epistolae, fragmenta (Vol. 1). Leipzig: B. G. Teubner.

Jacoby, K. (Ed.). (1885). Dionysius Halicarnanensis: Antiquitatum Romanarum quae supersunt (Vol. I-IV). Leipzig: B. G. Teubner.

Kaibel, G. (Ed.). (1887). Athenaeus: Deipnosophistae. Leipzig: B. G. Teubner.

Kirchner, J. (Ed.). (1913-1940). G II'2 Inscriptiones Graecae II et III: Inscriptiones Atticae Euclidis anno posteriores (2nd ed.; Parts I-III). Berlin.

Kucharský, P. (Transl.). (1976). Titus Livius: Dějiny V (Antická knihovna). Praha: Svoboda.

Mayhoff, K. F. Th. (Ed.). (1906). C. Plinius Secundus: Naturalis Historia. Leipzig: B. G. Teubner.

Meineke, A. (Ed.). (1877). Strabon: Geographica. Leipzig: B. G. Teubner.

Müller, Th., \& Müller, C. (Eds.). (1841-1873). Fragmenta historicorum graecorum ... auxerunt, notis et prolegomenis illustrarunt, indici plenissimo instruxerunt Car. et Theod. MULLERI. Accedunt marmora parium et rosettanum, hoc cum Letronnii, illud cum C. MULLERI commentariis. Parisiis: Editore Ambrosio Firmin Didot.

Nixon, P. (Transl.). (1917). T. Maccius Plautus, II: Cistellaria. London: William Heinemann.

Nixon, P. (Transl.). (1917). T. Maccius Plautus, II: Curculio. London: William Heinemann.

Oldfather, Ch. H. (Transl.). (1939). Diodorus of Sicily (Vol. III). London: William Heinemann.

Sabbadini, R. (Ed.). (1930). P. Vergilii Maronis Opera, II: Aeneis. Romae: Regia Officina Polygraphica.

Shepherd, R. (Transl.). (1793). Polyaenus: Translation of Strategematum libri octo. London: Printed for George Nicol.

Smart, Ch. (Transl.). (1863). The Works of Horace. Philadelphia: Joseph Whetham.

Stanley, T. (Transl.). (1665). Claudius Aelianus: His Various History. London: Printed for Thomas Dring.

Weissenborn, G., \& Müller, M. (Eds.). (1898). Titus Livius: Ab urbe condita libri I-X. Leipzig: B. G. Teubner.

\section{Secondary Sources}

Amann, P. (2017). Society, 580-450 BCE. In A. Naso (Ed.), Etruscology (pp. 985-1000). Boston Berlin: De Gruyter.

Amann, P. (2017). Society. In A. Naso (Ed.). Etruscology (pp. 179-194). Boston - Berlin: De Gruyter.

Barker, G., \& Rasmussen, T. B. (2005). Etruskové. Praha: Nakladatelství Lidové noviny.

Becker, H. (2006). Production, consumption and society in north Etruria during the archaic and classical periods: The world of Lars Porsenna. Diss. Department of Classics (Classical Archaeology), University of North Carolina.

Becker, H. (2016). Luxuria prolapsa est: Etruscan Wealth and Decadence. In S. Bell, \& A. A. Carpino (Eds.), A Companion to the Etruscans (pp. 293-304). Chichester, West Sussex: Wiley Blackwell.

Beekes, R. S. P. (2003). The origin of the Etruscans. Amsterdam: Koninklijke Nederlandse Akademie van Wetenschappen.

Bonfante Warren, L. (1973). Etruscan Women: A Question of Interpretation. Archaeology, 26, 242-249.

Bonfante, G. (1998). The Origin of Cannibalism in Dante. Etruscan Studies, 5, 3-6. 
Bruni, S. (2013). Seafaring: Ship Building, Harbors, the Issue of Piracy. In J. M. Turfa (Ed.), The Etruscan World (pp. 760-777). Abingdon: Routledge.

Camporeale, G. (2016). The Etruscans and the Mediterranean. In S. Bell, \& A. A. Carpino (Eds.), A Companion to the Etruscans (pp. 67-86). Chichester, West Sussex: Wiley Blackwell.

Carpino, A. A. (2016). The "Taste" for Violence in Etruscan Art: Debunking the Myth. In S. Bell, \& A. A. Carpino (Eds.), A Companion to the Etruscans (pp. 410-431). Chichester, West Sussex: Wiley Blackwell.

Carpino, A. A., \& Bell, S. (2016). Indroduction. In Idem, \& S. Bell (Eds.), A Companion to the Etruscans (pp. xxii-xxvii). Chichester, West Sussex: Wiley Blackwell.

Ceccarelli, L. (2016). The Romanization of Etruria. In S. Bell, \& A. A. Carpino (Eds.), A Companion to the Etruscans (pp. 28-40). Chichester, West Sussex: Wiley Blackwell.

Colivicchi, F. (2017). Banqueting and Food. In A. Naso (Ed.), Etruscology (pp. 207-220). Boston Berlin: De Gruyter.

Cristofani, M. (1999). Dizionario della civiltà etrusca. Firenze: Giunti.

Della Fina, G. M. (2005). Etruschi: la vita quotidiana. Rome: L'Erma di Bretschneider.

Isayev, E. (2016). Italy before the Romans. In A. Cooley (Ed.), A companion to Roman Italy (pp. 1-32). Chichester, West Sussex: Wiley Blackwell.

Krauskopf, I. (2016). Myth in Etruria. In S. Bell, \& A. A. Carpino (Eds.), A Companion to the Etruscans (pp. 388-409). Chichester, West Sussex: Wiley Blackwell.

Lomas, K. (2017). The Rise of Rome: From the Iron Age to the Punic Wars (1000 BC-264 BC). London: Profile Books.

Marincola, J. (2011). Introduction. In J. Marincola (Ed.), Greek and Roman historiography (pp. xviixxiv). Oxford: Oxford University Press.

Pallottino, M. (1942). Etruscologia. Milano: Hoepli.

Pieraccini, L. C. (2013). Food and drink in the Etruscan world. In J. M. Turfa (Ed.), The Etruscan World (pp. 812-822). Abingdon: Routledge.

Rallo, A. (1989). Le Donne in Etruria. Rome: L'Erma di Bretschneider.

Rawlings, L. (2007). Army and Battle during the Conquest of Italy (350-264 bc). In P. Erdkamp (Ed.), A Companion to the Roman Army (pp. 45-62). Chichester, West Sussex: Wiley Blackwell.

Rossi, M. (2013). A tavola con gli Etruschi. In F. R. Porcaroli (Ed.), Vino et Lustris. Il rito del Simposio: Soprintendenza e Guardia di Finanza a tutela del patrimonio archeologico del territorio (pp. 43-47). Roma: Gangemi Editore spa.

Stoddart, S. K. (2016). Beginnings: Protovillanovan and Villanovan Etruria. In S. Bell, \& A. A. Carpino (Eds.), A Companion to the Etruscans (pp. 3-14). Chichester, West Sussex: Wiley Blackwell.

Tagliamonte, G. (2017). Political organization and magistrate. In A. Naso (Ed.), Etruscology (pp. 121-241). Berlin: De Gruyter.

Turfa, J. M. (2016). The Obesus Etruscus: Can the Trope be True? In S. Bell, \& A. A. Carpino (Eds.), A Companion to the Etruscans (pp. 321-335). Chichester, West Sussex: Wiley Blackwell.

Weeber, K. W. (1979). Geschichte der Etrusker. Stuttgart: W. Kohlhammer. 
Etruscan Hedonism, Women, and Cruelty - Interpretation of Ancient Writings and Archaeological ...

Mgr. et Mgr. Kristína Rašlová / kristinaraslova@mail.muni.cz

Department of Archaeology and Museology

Masaryk University, Faculty of Arts

Arne Nováka 1/1, 60200 Brno, Czech Republic 